\title{
Ring opening reactions of tetrathiacyclopropenonophanes and the subsequent formation of a molecular box stabilised by hydrogen bonds
}

\author{
Daniel B. Werz, ${ }^{a}$ Rolf Gleiter, ${ }^{\mathrm{a} *}$ and Frank Rominger ${ }^{\mathrm{a}}$ \\ ${ }^{a}$ Organisch-Chemisches Institut der Universität Heidelberg, \\ Im Neuenheimer Feld 270, D-69120 Heidelberg, Germany \\ E-mail: rolf.gleiter@urz.uni-heidelberg.de
}

\section{Dedicated to Prof. Nikolay Zefirov on the occasion of his $70^{\text {th }}$ birthday}

(received 25 Nov 04; accepted 03 Feb 05; published on the web 04 Mar 05)

\begin{abstract}
Sulfur atoms next to a cyclopropenone moiety change their reactivity completely. Tetrathiacyclopropenonophanes $\mathbf{6}$ and $\mathbf{1 0}$ were treated with protic solvents such as methanol and water yielding ring opened diesters $9 \mathbf{a}$ and $\mathbf{9 b}$, and the diacid 11, respectively. This observation is in contrast to alkyl and aryl substituted cyclopropenones which are stable in the presence of protic solvents. The molecular structures of the diester and the diacid could be elucidated by means of X-ray diffraction analyses. In the latter case a molecular box was formed in such a way that the two acid moieties dimerise via hydrogen bonding. The resulting hollow core is able to host one molecule of chloroform.
\end{abstract}

Keywords: Cyclopropenones, ring opening reactions, sulfur compounds, supramolecular chemistry, inclusion compounds, X-ray structures

\section{Introduction}

Since the first synthesis of diphenylcyclopropenone ${ }^{1} \mathbf{1}$ by Breslow in 1959 , cyclopropenone chemistry has grown into several branches. The low kinetic stability ${ }^{2,3}$ of the unsubstituted parent compound can usually be increased by substitution with electron-donating or bulky groups. Hitherto, cyclopropenones with alkoxy, ${ }^{4}$ dialkylamino, ${ }^{5,6}$ alkylthio, ${ }^{7-9}$ alkylseleno, ${ }^{10}$ and alkyltelluro $^{10}$ (2) groups have been reported. A definite highlight in cyclopropenone chemistry is the synthesis and structural investigation of deltic acid ${ }^{11,12} \mathbf{3}$ bearing two free hydroxy groups. Also cyclophanes such as $\mathbf{4}$ and $\mathbf{5}$ consisting of tethered cyclopropenone moieties have been elucidated and characterized structurally as well as electronically. ${ }^{13-16}$ 


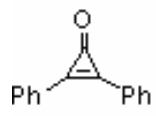

1

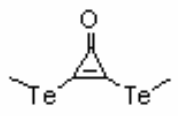

2

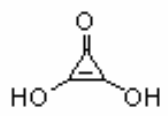

3

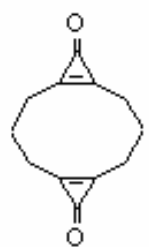

4

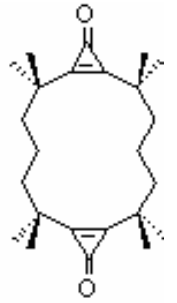

5

Recently a variety of reactions was investigated such as the transition metal catalysed reaction of cyclopropenone acetals with acetylenes to cyclopentadienones ${ }^{17-19}$ as well as the ring opening of selenium- and tellurium-substituted cyclopropenone moieties. ${ }^{10}$ In the first case the weak bond next to the carbonyl group is broken, in the latter the electron-poor carbon atom in the carbonyl group is attacked by nucleophiles.

In the present study we have performed ring-opening reactions of tetrathiacyclopropenonophanes ${ }^{9}$ initiated by the addition of protic solvents to the cyclopropenone moieties.

\section{Results and Discussion}

The reaction of tetrathiacyclopropenonophane $\mathbf{6}$ in a solution of dichloromethane with excess of methanol at room temperature yielded almost quantitatively a mixture of 9a and $9 \mathbf{b}$ in a 3:1 ratio (Scheme 1). The separation of the two regioisomers by column chromatography proved to be impossible.
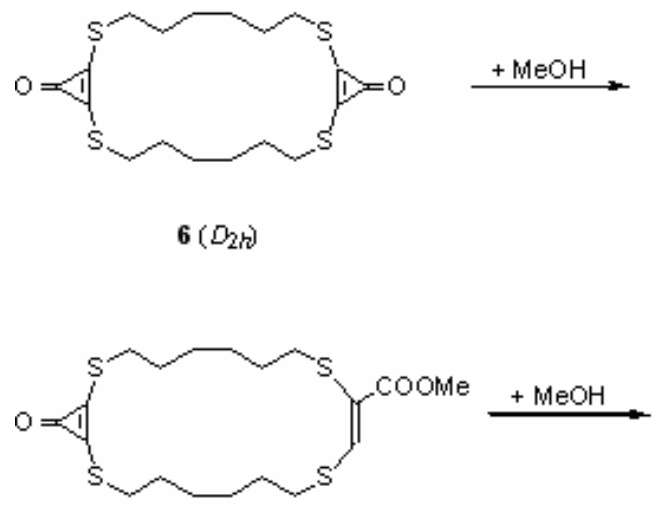

$8\left(C_{s}\right)$

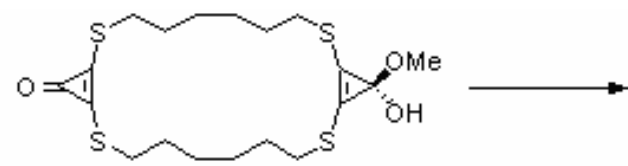

$7\left(C_{5}\right)$

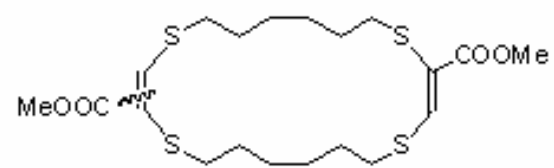

9a $\left(C_{2 h}\right)$ and $\mathbf{9 b}\left(C_{2 v}\right)$

\section{Scheme 1}




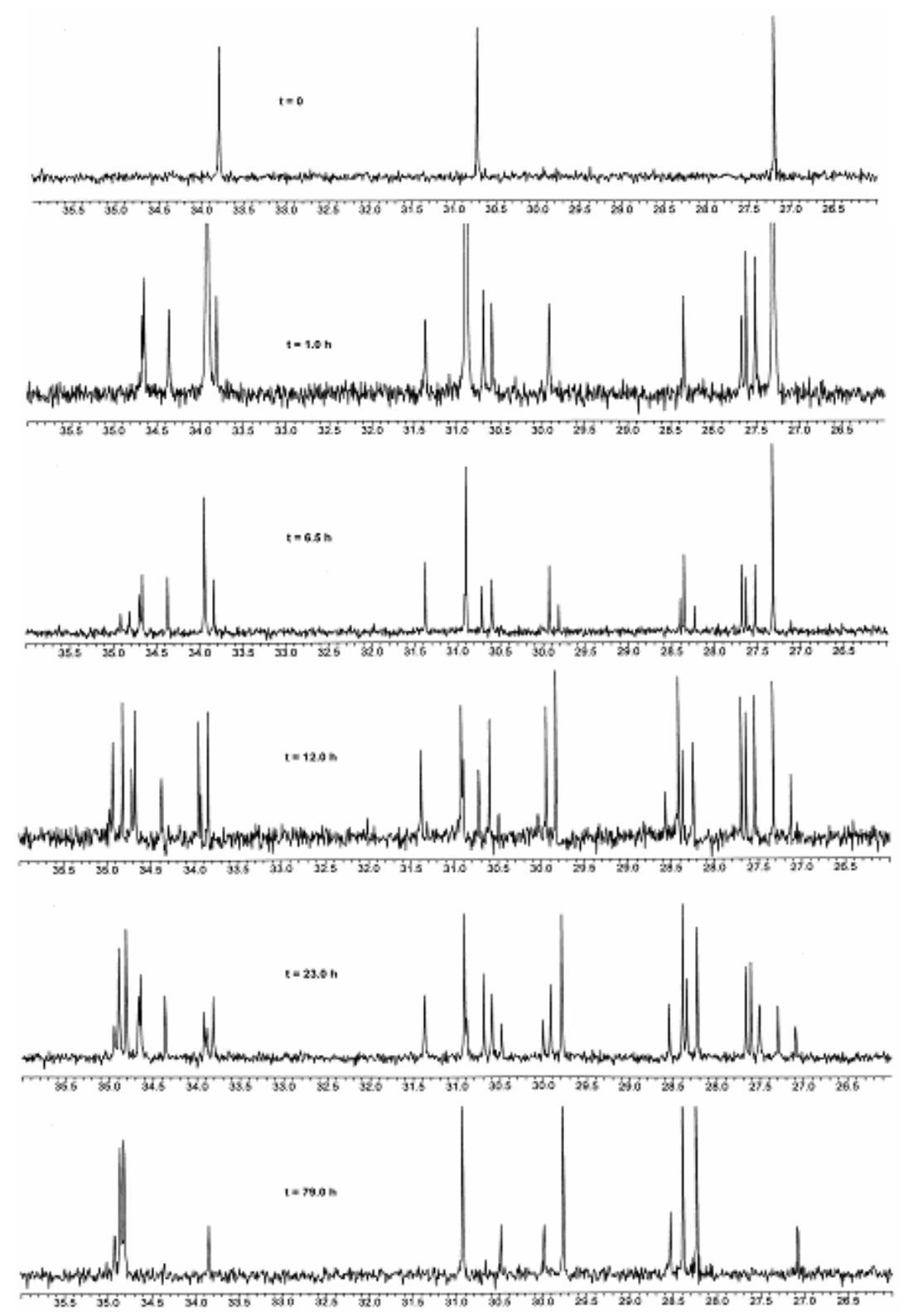

Figure 1. ${ }^{13} \mathrm{C}$ NMR spectra $(\delta=36-26)$ during the reaction of 6 to $9 \mathbf{a}$ and $9 \mathbf{b}$.

The reaction itself is quite slow and was monitored in a separate experiment by NMR spectroscopy over a period of three days. Figure 1 shows the corresponding ${ }^{13} \mathrm{C}$ NMR spectra in the range of $\delta=36-26$ for different reaction times. This is the region where all carbon resonance signals of the $\mathrm{CH}_{2}$ tethers appear. Before staring the reaction, the spectrum shows three signals being in line with the $D_{2 h}$ symmetry of the starting material 6. After $\mathrm{t}=1.0 \mathrm{~h}$ twelve further 
signals appeared. These signals correspond to a compound where all carbon atoms in the tethers are different giving rise to a $\mathrm{C}_{s}$ symmetric molecule. We ascribe this set of signals to compound 8 in which one cyclopropenone moiety has opened to from an ester unit. A potential acetal structure 7 with a mirror plane orthogonal to the plane of the large cycle would show only a set of six signals in this region. One can conclude that such a molecule that is presumably an intermediate before $\mathbf{8}$ is formed, is either too short-living compared to the NMR timescale or the concentration is too low. Thus, it cannot be observed by this method.

After a $12.0 \mathrm{~h}$ reaction period at least 28 signals can be discerned: still three signals of the starting material $\mathbf{6}$ are present, twelve of the monoester $\mathbf{8}$ and several other (new) signals giving rise to the final products $9 \mathbf{a}$ and $9 \mathbf{b}$. The last measurement after $\mathrm{t}=79.0 \mathrm{~h}$ shows two sets of six signals in the final ratio of $3: 1$. The reaction was also followed by means of ${ }^{1} \mathrm{H}$ NMR spectroscopy. Here, the most characteristic signals are the alkene protons of the three different alkenes 8,9a and $9 \mathrm{~b}$ in the range between 8.0 and $8.1 \mathrm{ppm}$. The reason why one of the two regioisomers is dramatically favored must be due to conformational preference and spatial requirements in the ring opening of the second hemiacetal formed from $\mathbf{8}$.

A similar reaction with water instead of methanol was carried out with the smaller homologue 10. In contrast to the former results, a ring opening did not take place, even experiments where the mixture was heated or the nucleophilicity of water was increased by addition of $\mathrm{NaOH}$ were in vain. Nevertheless, by adding a catalytic amount (three drops) of hydrochloric acid the ring opening yielding 11 succeeded (Scheme 2). However, many byproducts were formed as mass spectrometric investigations revealed. A chromatographic separation of the compounds proved to be unsuccessful, therefore a separation by means of crystallisation was performed. However, the amount of material obtained by this method was not sufficient for any NMR studies.

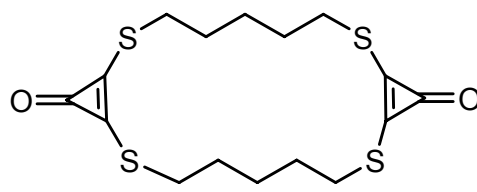

10
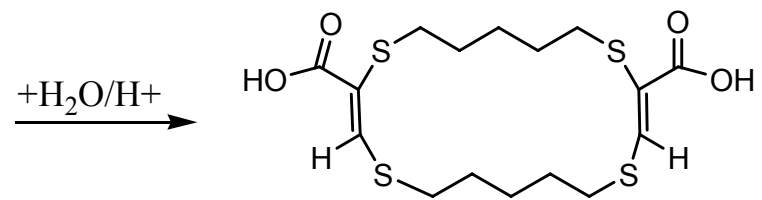

11

\section{Scheme 2}

Single crystals of 9a and $\mathbf{1 1}$ were obtained and investigated by X-ray diffraction studies. In Figure 2 we display the molecular structure of $9 \mathbf{a}$. The unit cell shows a center of symmetry as the molecule also does. The alkyl tethers obtain a strain-free zig-zag conformation. 


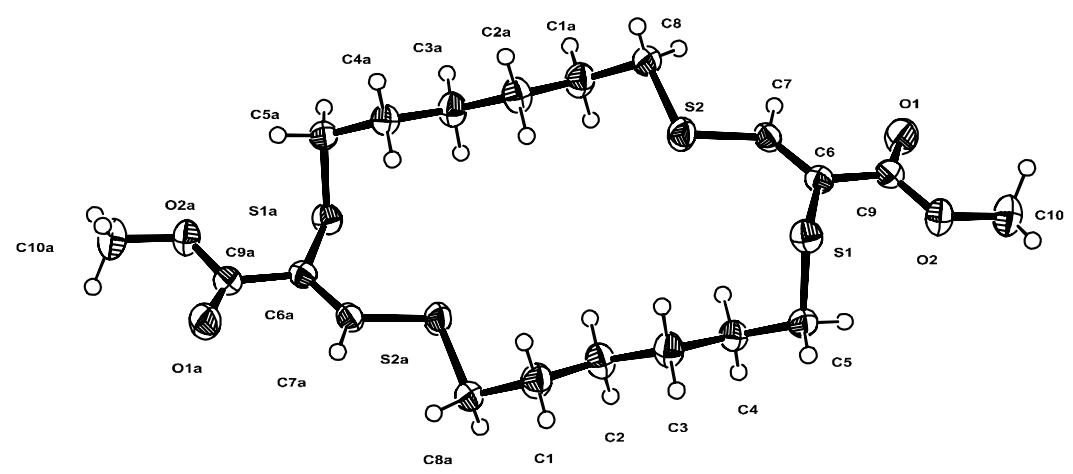

Figure 2. ORTEP $\mathrm{P}^{20}$ plot $(50 \%$ ellipsoid propability, crystallographic numbering) of the molecular structure of $\mathbf{9 a}$.

The unit cell of the diacid $\mathbf{1 1}$ reveals two independent molecules. Each of them dimerises with a corresponding symmetry-equivalent molecule which is generated by rotation around a $C_{2}$ axis. In such a way a hollow core is formed that is able to include one molecule of chloroform. These guest molecules are located on the $C_{2}$ axis and are disordered in a 1:1 ratio. Such a molecular aggregate of $\mathbf{1 1}$ with included chloroform is shown in Figure 3.

The special feature of this hollow core is strongly determined by the push-pull-substituted $\mathrm{C}=\mathrm{C}$ bond. As anticipated by simple resonance structures the $\mathrm{SCH}_{2}$ moiety which is located trans to the ester moiety is in plane with the double bond, whereas the other $\mathrm{SCH}_{2}$ unit which is situated geminal to the ester moiety adopts a perpendicular position. Thus, one side of the cavity shows a wider opening than the other.

In summary, the reactions of tetrathiacyclopropenonophanes ${ }^{9}$ with protic media were investigated. Methanol as well as water is able to attack the cyclopropenone moiety and to form an acrylic ester or an acrylic acid moiety, respectively. Structural investigations of the diacid $\mathbf{1 1}$ have shown a dimeric structure giving rise to a hollow core being able to host chloroform molecules. 

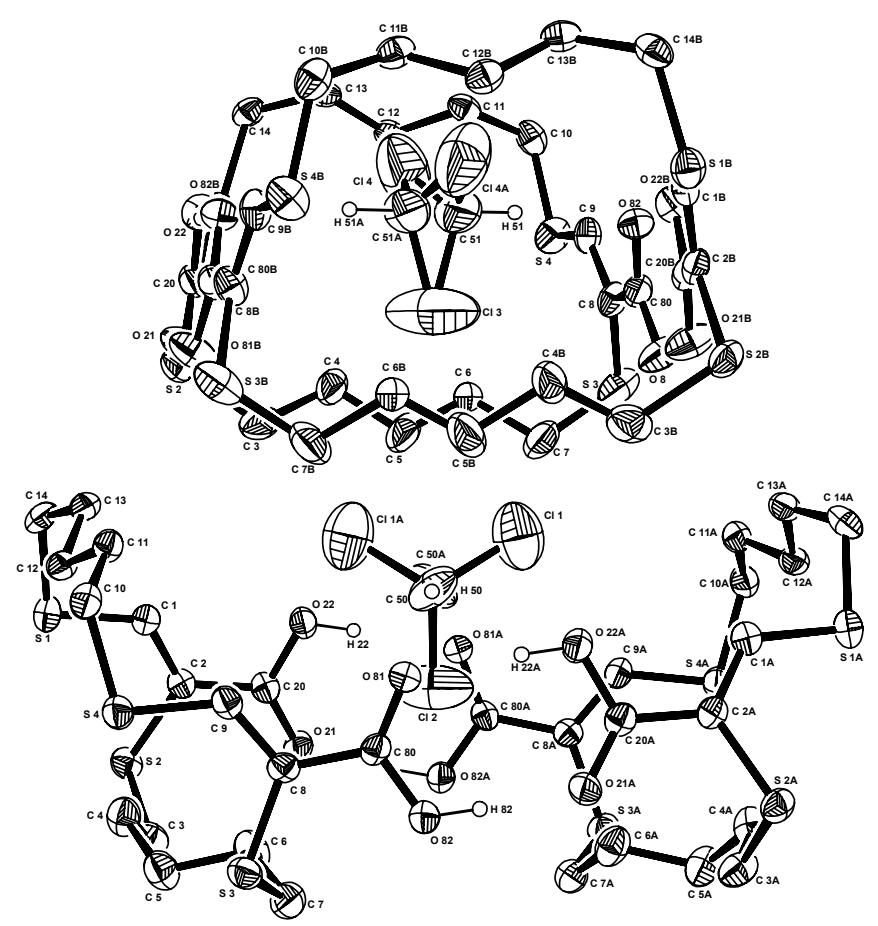

Figure 3. ORTEP $^{20}$ plot (crystallographic numbering) of the molecular structure of 11 showing included chloroform.

\section{Experimental Section}

1,11-Bis(methoxycarbonyl)-3,10,13,20-tetrathiacyclo-1,11-eicosadiene (9a) and 1,12bis(methoxycarbonyl)-3,10,13,20-tetrathiacyclo-1,11-eicosadiene (9a). $47 \mathrm{mg}$ (0.118 mmol) of 6 is reacted in $20 \mathrm{ml}$ of dichloromethane with $2 \mathrm{ml}$ of methanol. The reaction mixture is stirred for 2 days at room temperature. Solvent is removed by rotary evaporation. A mixture of the desired products (9a and 9b) precipitated as a colorless solid. For elemental analysis a colunm chromatography (Alox III) with petroleum ether / ethyl acetate (10:1) as eluent was performed. Yield: $53 \mathrm{mg}(97 \%)$. Analytical data of 9a: $\mathrm{Mp} 140^{\circ} \mathrm{C} .{ }^{1} \mathrm{H} \mathrm{NMR}\left(500 \mathrm{MHz}, \mathrm{CDCl}_{3}\right)$ : $\delta=1.38\left(\mathrm{~m}, 4 \mathrm{H}, \mathrm{CH}_{2}\right), 1.47\left(\mathrm{~m}, 8 \mathrm{H}, \mathrm{CH}_{2}\right), 1.65\left(\mathrm{~m} .4 \mathrm{H}, \mathrm{CH}_{2}\right), 2.72\left(\mathrm{~m}, 4 \mathrm{H}, \mathrm{SCH}_{2}\right), 2.82(\mathrm{~m}, 4 \mathrm{H}$, $\left.\mathrm{SCH}_{2}\right), 3.75\left(\mathrm{~s}, 6 \mathrm{H}, \mathrm{CH}_{3}\right), 8.01 / 8.10(\mathrm{~s}, 2 \mathrm{H}, \mathrm{C}=\mathrm{CH}) .{ }^{13} \mathrm{C} \mathrm{NMR}\left(125 \mathrm{MHz}, \mathrm{CDCl}_{3}\right): \delta=26.7 /$ 27.9 / $28.0 / 29.4$ / 29.6 / $30.0 / 30.4\left(\mathrm{CH}_{2}\right), 33.7$ / 34.6 / 34.6 / $34.6\left(\mathrm{SCH}_{2}\right), 52.3\left(\mathrm{CH}_{3}\right), 118.2$ /118.8 $(\mathrm{HC}=C), 155.5 / 157.0(\mathrm{HC}=\mathrm{C}), 164.3 / 164.4(C=\mathrm{O}) . \mathrm{IR}(\mathrm{KBr})\left[\mathrm{cm}^{-1}\right]: 2924(\mathrm{~s}), 2847$ (m), 1854 (s), 1688 (s), 1526 (s), 1258 (s), 1233 (s), 1040 (m). UV $\left(\mathrm{CH}_{2} \mathrm{Cl}_{2}\right): \lambda_{\max }$ [nm] (lg E): 294 (4.30). HRMS (FAB+): calcd. $\left(\mathrm{C}_{20} \mathrm{H}_{32} \mathrm{O}_{4} \mathrm{~S}_{4}\right)$ 464.1184, found 464.1200. Anal. calcd. for $\mathrm{C}_{20} \mathrm{H}_{32} \mathrm{O}_{4} \mathrm{~S}_{4}$ : C, 51.69; H, 6.94; S 27.60. Found: C, 51.65; H, 6.95; S, 27.65. Crystals suitable for 
X-ray crystallography were obtained by crystallisation out of dichloromethane / $n$-hexane (1:3) by evaporation at room temperature. Crystal data of 9a: Monoclinic, $a=11.0944(1) \AA, b=$ 5.5661(1) $\AA, c=19.4892(3) \AA, V=1184.31(3) \AA^{3}$, space group $P 2_{1} / \mathrm{c}, Z=2, D_{\mathrm{c}}=1.303 \mathrm{~g} \mathrm{~cm}^{-3}$, $F(000)=496$, polyhedron, $0.50 \times 0.15 \times 0.07 \mathrm{~mm}^{3}, \mu=0.424 \mathrm{~mm}^{-1}$, reflections collected 11450 , independent reflections 2694, observed reflections $1956, R 1=0.042, w R 2=0.104, S(\mathrm{Gof})=$ $1.01,(\Delta \rho)_{\max }=0.48 \mathrm{e} \AA^{-3},(\Delta \rho)_{\min }=-0.29 \mathrm{e}^{-3}$.

3,9,12,18-Tetrathiacyclooctadeca-1,10-diene-1,11-dicarboxylic acid (11). $27 \mathrm{mg}$ $(0.070 \mathrm{mmol})$ of $\mathbf{1 0}$ is reacted in $2 \mathrm{ml}$ of chloroform with $0.2 \mathrm{ml}$ of water and a catalytic amount (three drops) of hydrochloric acid. The reaction mixture is stirred for 5 days at room temperature. Solvent is removed by rotary evaporation as most as possible. After several days a slightly yellow crystalline compound precipitated being 11. Yield: $6 \mathrm{mg}(20 \%)$. IR (KBr) $\left[\mathrm{cm}^{-1}\right]: 3434$ (b), 2929 (m), 2853 (m), 1667 (s), 1526 (s), 1268 (m), 1011 (w). UV $\left(\mathrm{CH}_{2} \mathrm{Cl}_{2}\right)$ : $\lambda_{\max }[\mathrm{nm}](\mathrm{lg} \varepsilon)$ : 288 (4.35). HRMS (FAB+): calcd. $\left(\mathrm{C}_{16} \mathrm{H}_{24} \mathrm{O}_{4} \mathrm{~S}_{4}\right) 408.0558$, found 408.0560. Crystals suitable for $\mathrm{X}$-ray crystallography were obtained by crystallisation out of the reaction mixture by evaporation at room temperature. Crystal data: Monoclinic, $a=25.9618(3) \AA, b=14.5977(3) \AA, c=$ 25.1322(4) $\AA, V=8959.0(3) \AA^{3}$, space group $C 2 / \mathrm{c}, Z=16, D_{\mathrm{c}}=1.389 \mathrm{~g} \mathrm{~cm}^{-3}, F(000)=3920$, polyhedron, $0.26 \times 0.16 \times 0.10 \mathrm{~mm}^{3}, \mu=0.622 \mathrm{~mm}^{-1}$, reflections collected 45626 , independent reflections 10258 , observed reflections $3989, R 1=0.068, w R 2=0.139, S(\mathrm{Gof})=0.95,(\Delta \rho)_{\max }=$ $0.56 \mathrm{e}^{-3},(\Delta \rho)_{\min }=-0.60 \mathrm{e} \AA^{-3}$.

\section{Supplementary information}

CCDC-255705 (9a) and CCDC-255706 (11) contain the supplementary crystallographic data for this paper. These data can be obtained free of charge at www.ccdc.cam.ac.uk/conts/retrieving.html or from the Cambridge Crystallographic Data Centre, 12 Union Road, Cambridge CB2 1EZ, UK; FAX: +44-1223-336-033; E-mail: data_request@ccdc.cam.ac.uk

\section{Acknowledgements}

We are grateful to the Deutsche Forschungsgemeinschaft, the Fonds der Chemischen Industrie and BASF Aktiengesellschaft, Ludwigshafen, for financial support. D.B.W. is grateful to the Studienstiftung des deutschen Volkes for a graduate fellowship. 


\section{References and Notes}

1. Breslow, R.; Haynie, R.; Mirra, J. J. Am. Chem. Soc. 1959, 81, 247.

2. Greenberg, A.; Tomkins, R. P. T.; Dobrovolny, M.; Liebman, J. F. J. Am. Chem. Soc. 1983, $105,6855$.

3. Dahn, H.; Ling-Truong, M.-N. Helv. Chim. Acta 1987, 70, 2130.

4. Eggerding, D.; West, R. J. Am. Chem. Soc. 1976, 98, 3641.

5. Yoshida, Z.; Konishi, H.; Tawara, Y.; Nishikawa, K.; Ogoshi, H. Tetrahedron Lett. 1973, 14, 2619.

6. Wilcox, C.; Breslow, R. Tetrahedron Lett. 1980, 21, 3241.

7. Dehmlow, E. V. Chem. Ber. 1968, 101, 410.

8. Weiss, R.; Schlierf, C.; Schloter, K. J. Am. Chem. Soc. 1976, 98, 4668.

9. Werz, D. B.; Rominger, F.; Hyla-Kryspin, I.; Gleiter, R. J. Org. Chem. 2001, 66, 3416.

10. Werz, D. B.; Gleiter, R.; Rominger, F. Eur. J. Org. Chem. 2003, 151.

11. Eggerding, D.; West, R. J. Am. Chem. Soc. 1975, 97, 207.

12. Semmingsen, D.; Groth, P. J. Am. Chem. Soc. 1987, 109, 7238.

13. Gleiter, R.; Merger, M. Synthesis 1995, 969.

14. Gleiter, R.; Merger, M.; Altreuther, A.; Irngartinger, H. J. Org. Chem. 1995, 60, 4692.

15. Gleiter, R.; Merger, M.; Altreuther, A.; Irngartinger, H. J. Org. Chem. 1996, 61, 1946.

16. Schuster, A.; Dissertation, Universität Heidelberg 1999.

17. Boger, D. L.; Brotherton, C. E. J. Am. Chem. Soc. 1986, 108, 6695.

18. Nakamura, M.; Isobe, H.; Nakamura, E. Chem. Rev. 2003, 103, 1295.

19. Isobe, H.; Sato, S.; Tanaka, T.; Tokuyama, H.; Nakamura, E. Org. Lett. 2004, 6, 3569.

20. Ortep-3 for Windows: A Version of Ortep-III with a Graphical User Interface (GUI): L. J. Farrugia, J. Appl. Crystallogr. 1997, 30, 565. 